\title{
Badania połączeń miedzianych zgrzewanych ultradźwiękowo
}

DOI: http://dx.doi.org/10.26628/ps.v90i8.921

\section{Investigations of copper joints welded by ultrasonic}

\section{Streszczenie}

W artykule przedstawiono wyniki badań zamknięcia szczelnego rurek miedzianych zgrzewanych ultradźwiękowo. Zakres pracy obejmował próbę szczelności, tomografię komputerową i badania metalograficzne. Wyniki przeprowadzonych badań wykazały istotny wpływ czynników technologicznych takich jak: czystość powierzchni miedzi, siła docisku oraz zużycie narzędzi zgrzewarki na jakość połączenia.

Słowa kluczowe: zgrzewanie ultradźwiękowe; połączenia miedziane; badania metalograficzne; próba szczelności; tomografia komputerowa

\section{Wstęp}

Zgrzewanie ultradźwiękowe jest sposobem spajania na zimno w stanie stałym, powszechnie stosowanym $w$ łączeniu tworzyw sztucznych [1]. Znalazło ono zastosowanie także do zgrzewania metali, które cechuje duża plastyczność, głównie takich jak aluminium, magnez, miedź i ich stopy [2,3]. Metoda ta pozwala na wykonywanie połączeń jedno-

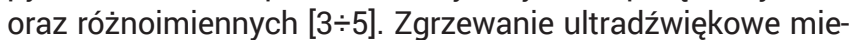
dzi znalazło szerokie zastosowanie w przemyśle chłodniczym i klimatyzacyjnym [4], motoryzacyjnym [5], elektrycznym, elektronicznym, lotniczym, a także w wytwarzaniu przedmiotów o zastosowaniu medycznym. Ze względu na wielkość i prostotę budowy urządzenia do zgrzewania ultradźwiękowego metoda cechuje się dużą mobilnością i małymi wymiarami narzędzi zgrzewających, co pozwala na zastosowanie procesu zgrzewania zarówno w produkcji, w montażu oraz w pracach naprawczych układów chłodzących.

W pracy zostały poddane ocenie złącza z miedzi gat. CuDHP zgrzewane ultradźwiękowo. Przeprowadzono badania metalograficzne, mające na celu wykrycie ewentualnych niezgodności występujących w złączach. Zgłady metalograficzne zostały wykonane na różnych długościach wzdłuż zgrzeiny każdej z badanych próbek w celu kompleksowej oceny jakości połączenia. Dzięki takiemu schematowi badań możliwe było wskazanie ewentualnych niezgodności, niezależnie od miejsca ich występowania w złączu.

\section{Charakterystyka procesu}

Zgrzewanie jest to proces łączenia materiałów, w którym złącze powstaje na skutek działania wyłącznie samego docisku, docisku i ciepła albo też docisku i innych zjawisk fizycznych jak np. drgań ultradźwiękowych. Połączenie materiałów występuje w wyniku procesów, sprężysto-plastycznego odkształcenia, które mają miejsce w płaszczyźnie zgrzewania, a także w wyniku dyfuzji.

Według hipotezy dyfuzyjnej zgrzewania ultradźwiękowego proces łączenia przebiega dwuetapowo - adhezyjnie i dyfuzyjnie. Pierwsze mostki połączeń powstają dzięki adhezji, kiedy elementy są zbliżone do siebie na odpowiednio bliską odległość (rys. 1). W kolejnym etapie znaczącą rolę

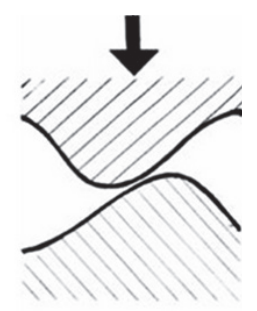

przed połączeniem

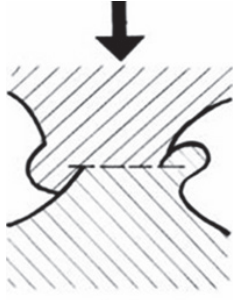

mostek połączenia

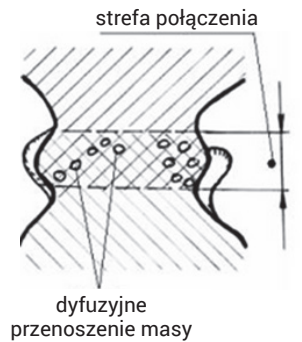

Rys. 1. Schemat formowania i rozrostu mostków połączeń dzięki procesom dyfuzyjnym [6]

Fig. 1. Scheme of formation and growth of connection bridges due to diffusion processes [6]

Prof. dr hab. inż. Andrzej Ambroziak, dr inż. Piotr Białucki, dr inż. Artur Lange, dr inż. Grzegorz Ziółkowski, dr inż. Wiesław Derlukiewicz, inż. Karolina Goławska - Politechnika Wrocławska.

Autor korespondencyjny/Corresponding author: artur.lange@pwr.edu.pl 
odgrywa dyfuzja. Siłą powodującą proces dyfuzji jest tendencja do zmniejszania powierzchniowej energii swobodnej układu.

Zgodnie z hipotezą rekrystalizacyjną, połączenie następuje wskutek rozrostu nowych ziaren, rosnących kosztem ziaren łączonych materiałów. Połączenie części następuje w wyniku tarcia, które ma miejsce w płaszczyźnie styku. Tarcie rozbija warstwę tlenków oraz nagrzewa powierzchnie do $0,3 \div 0,6$ temperatury topnienia [6].

Na rysunku 2 został przedstawiony rozwój tworzenia się stref stykowych oraz połączenia podczas zgrzewania ultradźwiękowego.
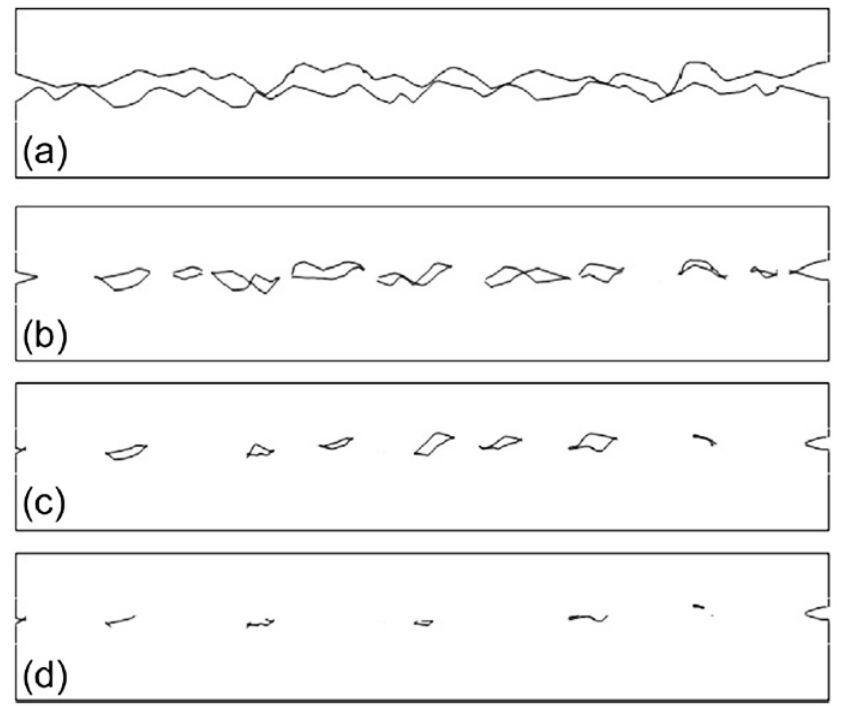

Rys. 2. Etapy tworzenia stref styku oraz połączenia podczas zgrzewania ultradźwiękowego; a), b), c), d) - etapy zgrzewania [7]

Fig. 2. The stages of creating contact zones and joint during ultrasonic welding; a), b), c), d) - welding stages [7]

Podczas zgrzewania, gdy drgania ultradźwiękowe są wzbudzane, górna część przesuwa się względem dolnej poprzecznym, ciernym ruchem. Występujące odkształcenia plastyczne oraz siły ścinające powodują oczyszczanie powierzchni, usuwanie tlenków, dzięki czemu zwiększany jest kontakt obu elementów - np. metalu z metalem. Nieprzerwane wibracje są przyczyną zwiększania obszarów styku, w związku z czym tworzą się kolejne strefy zgrzania, aż do prawie całkowitego kontaktu i połączenia powierzchni elementów [7].

Do zalet procesu łącznia z wykorzystaniem ultradźwięków zaliczamy:

- możliwość łączenia prawie wszystkich metali technicznych o różnych właściwościach fizycznych i grubościach;

- dobre właściwości mechaniczne, elektryczne i korozyjne złączy;

- bardzo małe moce zgrzewania;

- wprowadzenie niewielkiej ilości ciepła do złącza;

- możliwość automatyzacji procesu.

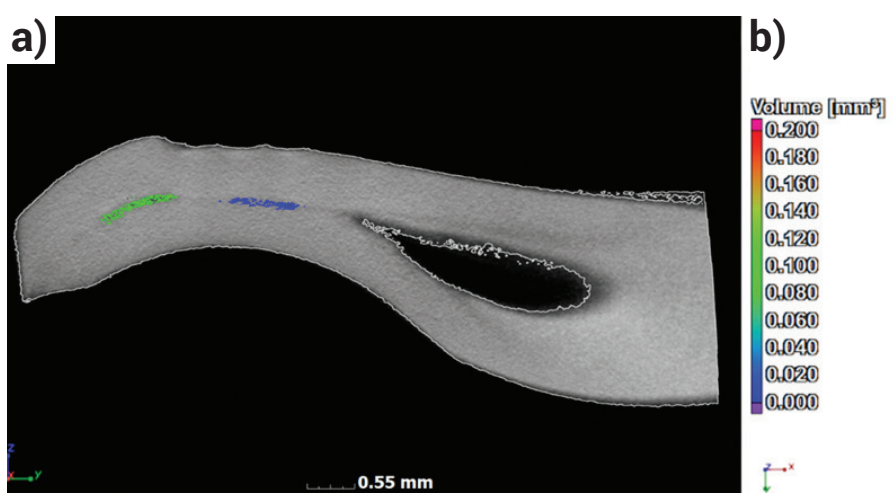

\section{Próba szczelności}

Próbę szczelności zgrzein tworzących zamknięcia rurek miedzianych wykonano metodą ciśnieniową wtłaczając do rurki powietrze pod ciśnieniem 0,6 MPa wynikającym z obciążeń eksploatacyjnych. Po zanurzeniu badanego złącza w wodzie obserwowano uwalnianie się pęcherzyków powietrza ze złącza w przypadku złączy wykazujących nieszczelność (rys. 3). Na osiem próbek pobranych z linii produkcyjnej nieszczelność stwierdzono w dwóch złączach zgrzewanych.

Zastosowana próba szczelności zgrzeiny zamykającej rurkę miedzianą jest metodą szybką, łatwą do przeprowadzenia, prostą w interpretacji a uzyskane wyniki zostały w pełni potwierdzone dalszymi badaniami.

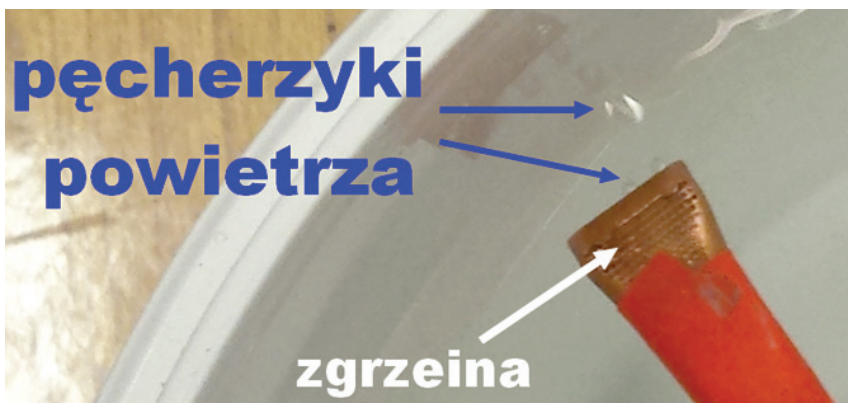

Rys. 3. Wynik próby szczelności złącza zgrzewanego ultradźwiękowo Fig. 3. Results of the tightness test of the ultrasonic welded joint

\section{Badania na tomografie komputerowym}

Złącza wykazujące nieszczelność poddano badaniom na tomografie komputerowym wykonując tzw. rekonstrukcję badanego złącza, która pozwala na przestrzenną analizę budowy zgrzeiny. Rekonstrukcję przeprowadzono z wykorzystaniem systemu CT METROTOM 1500 firmy Carl Zeiss, stosując napięcie lampy rentgenowskiej o wartości 220 kV, natężenie prądu lamy o wartości $40 \mu \mathrm{A}$ z czasem integracji pojedynczej projekcji na poziomie $2 \mathrm{~s}$. W celu redukcji artefaktów pomiarowych zastosowano filtr miedziany o grubości $0,5 \mathrm{~mm}$. Zastosowane parametry pozwoliły na rekonstrukcję złącza z rozdzielczością 9,81 $\mu \mathrm{m}$. Wynik rekonstrukcji przedstawiono na rysunkach 4 i 5.

Na rysunku 4a przedstawiono przekrój CT w płaszczyźnie równoległej do powierzchni zgrzeiny z zaznaczonymi kolorem nieciągłościami wewnątrz zgrzeiny. Rysunek 4b przedstawia widok 3D z zaznaczoną płaszczyzną i widocznym rozkładem przestrzennym nieciągłości zarejestrowanych wewnątrz zgrzeiny. Rysunek 5a przedstawia przekrój CT w płaszczyźnie prostopadłej do powierzchni złącza (płaszczyźnie, w jakiej wykonano zgłady metalograficzne), natomiast rysunek $5 \mathrm{~b}$ przedstawia widok 3D z zaznaczoną płaszczyzną przekroju.

W wyniku analizy danych tomograficznych wykazano występowanie nieciągłości wewnątrz zgrzeiny. Maksymalna objętość nieciągłości wewnątrz zgrzeiny wynosiła $0,106 \mathrm{~mm}^{3}$

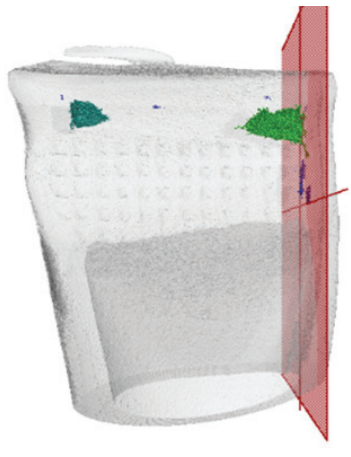

Rys. 4. Wynik rekonstrukcji CT: a) Przekrój 2D płaszczyzną prostopadłą do powierzchni zgrzeiny, b) widok 3D z widoczną płaszczyzną przekroju. Kolorami zaznaczono objętość zarejestrowanych nieciągłości

Fig. 4. The CT reconstruction result: a) $2 \mathrm{D}$ cross-section with a plane perpendicular to the weld surface, b) 3D view with a visible plane of the crosssection. The volume of recorded discontinuities is marked with colors 

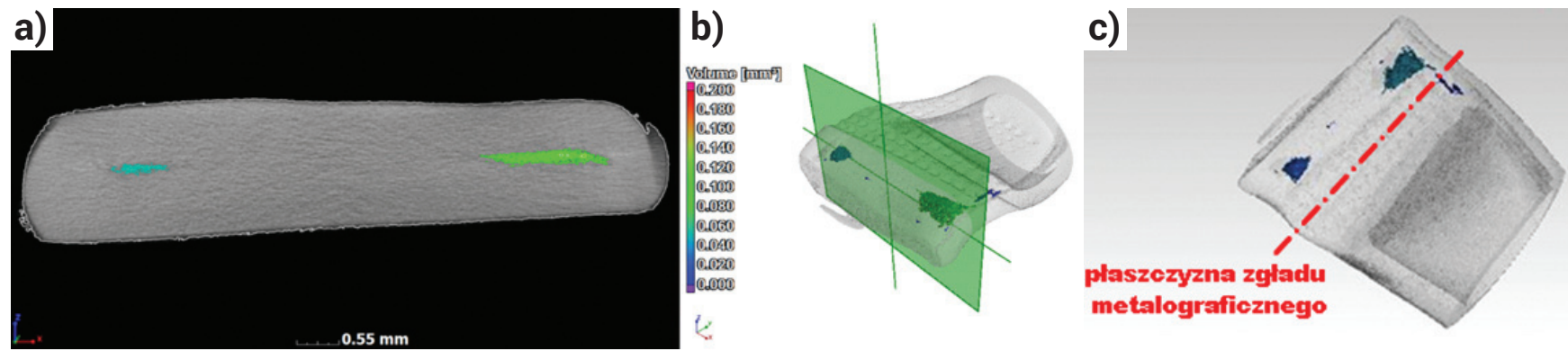

Rys. 5. Wynik rekonstrukcji CT: a) Przekrój 2D płaszczyzną prostopadłą do powierzchni zgrzeiny, b) widok 3D z widoczną płaszczyzną przekroju, c) płaszczyzna zgładu metalograficznego. Kolorami zaznaczono objętość zarejestrowanych nieciągłości

Fig. 5. The result of CT reconstruction: a) 2D cross-section with a plane perpendicular to the weld surface, b) 3D view with a visible plane of the section, c) metallographic plane. The volume of recorded discontinuities is marked with colors

(nieciągłość zaznaczona kolorem zielonym na rysunkach 4 i 5). Średnice zarejestrowanych nieciągłości mieściły się w granicach od $0,047 \mathrm{~mm}$ do $2,282 \mathrm{~mm}$.

\section{Badania metalograficzne}

W badaniach metalograficznych obserwowano powierzchnie zgładów poprzecznych złączy zgrzewanych trawionych $20 \%$ roztworem nadsiarczanu amonu. Celem przeanalizowania budowy zgrzeiny na całej długości złącza, zgłady szlifowano stopniowo i wykonywano kolejne mikrofotografie struktury zgrzeiny po zeszlifowaniu materiału złącza o grubości ok. 0,5 mm.

Na rysunku 6 pokazano makrofotografie przykładowego złącza na początku zgrzeiny (a), w trakcie (b) oraz pod koniec procesu zgrzewania (c). Widać na nich wyraźne różnice w budowie zgrzeiny na jej długości. Na początku zgrzewania w środku zgrzeiny występuje widoczny już styk materiału rurki, z lewej strony występuje niewielka szczelina, a z prawej strony na brzegu jest jeszcze duża pustka na linii styku (rys. 6a). W dalszym cyklu zgrzewania zanikają pustki na końcach złącza (rys. 6b), a w końcowym etapie powstaje złącze na całej linii styku (rys. 6c).

Wygląd poprawnie wykonanego połączenia przedstawiono na rysunku 7 , które charakteryzuje się mostkami dyfuzyjnymi i ziarnami rekrystalizacyjnymi. Pomiędzy mostkami występują cienkie warstewki tlenków, które zostały usunięte w procesie zgrzewania, ale one nie są problemem nieszczelności złącza.

Na rysunkach 8 i 9 przedstawiono widoki złączy, które wykazały nieszczelność w próbie pęcherzykowej. Na rysunku 8
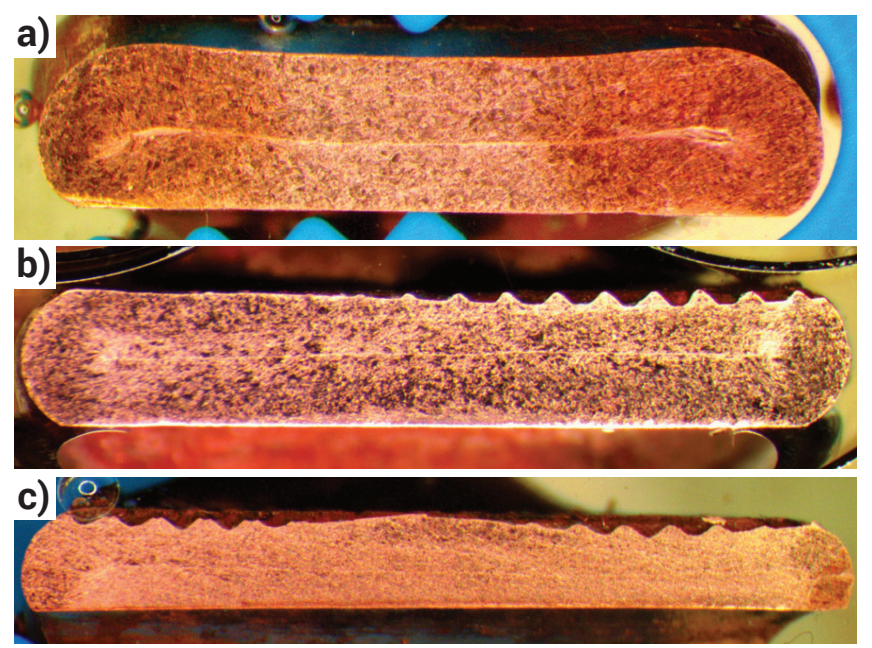

Rys. 6. Makrofotografie złącza zgrzewanego ultradźwiękowo: a) na początku, b) w trakcie i c) pod koniec cyklu zgrzewania. Pow. 20x.

Fig. 6. Macrophotographs of the ultrasonic welded joint: a) at the beginning, b) during and c) at the end of the welding cycle. Mag. 20x
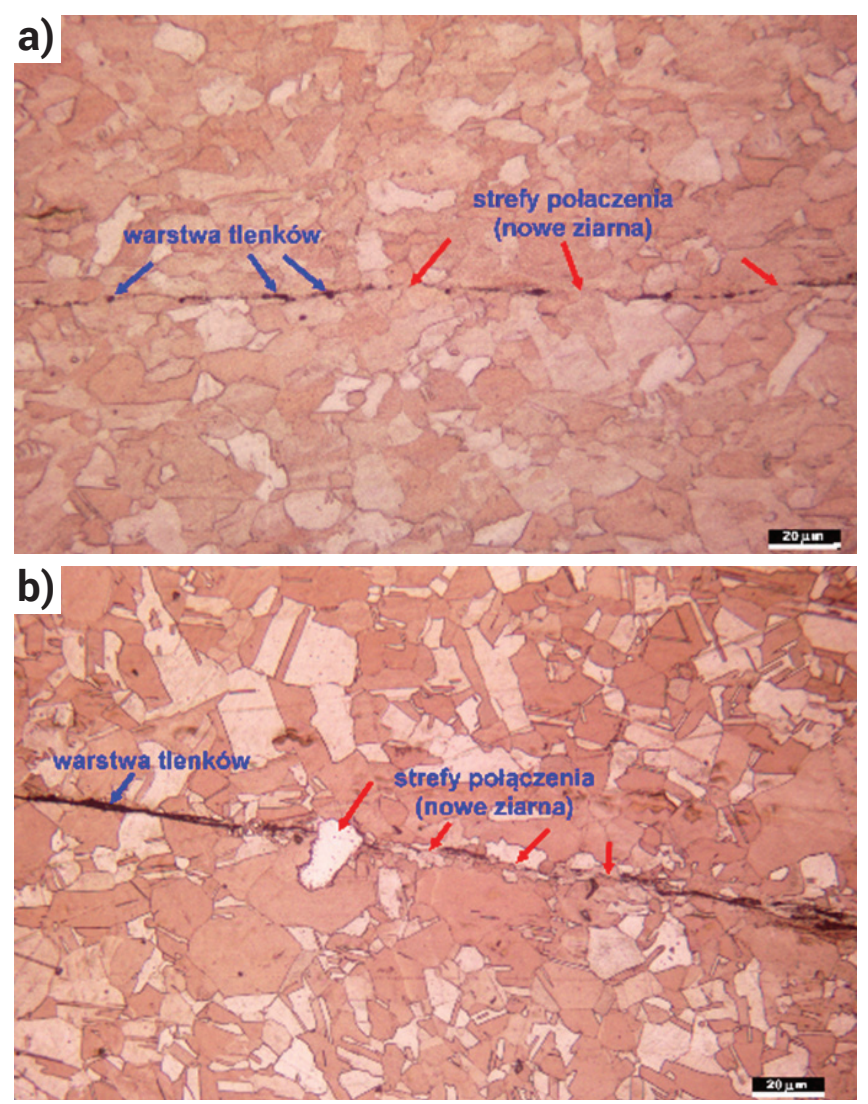

Rys. 7. Mikrofotografie złącza zgrzewanego ultradźwiękowo w środkowej części połączenia

Fig. 7. Microphotographs of the ultrasonic welded joint in the middle part of the connection

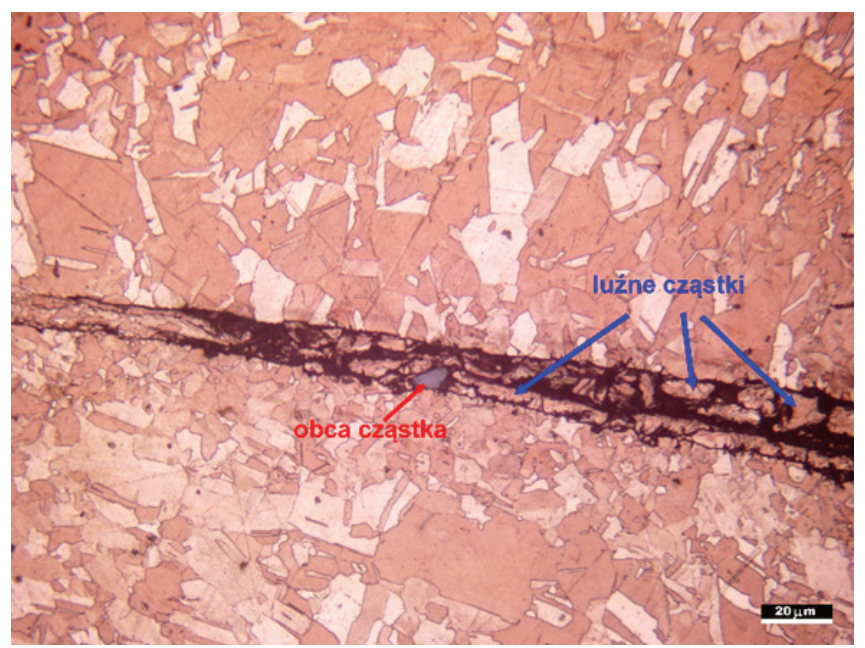

Rys. 8. Mikrofotografie złącza zgrzewanego ultradźwiękowo na jednym z końców połączenia

Fig. 8. Microphotographs of the ultrasonic welded joint at one of the ends of the connection 

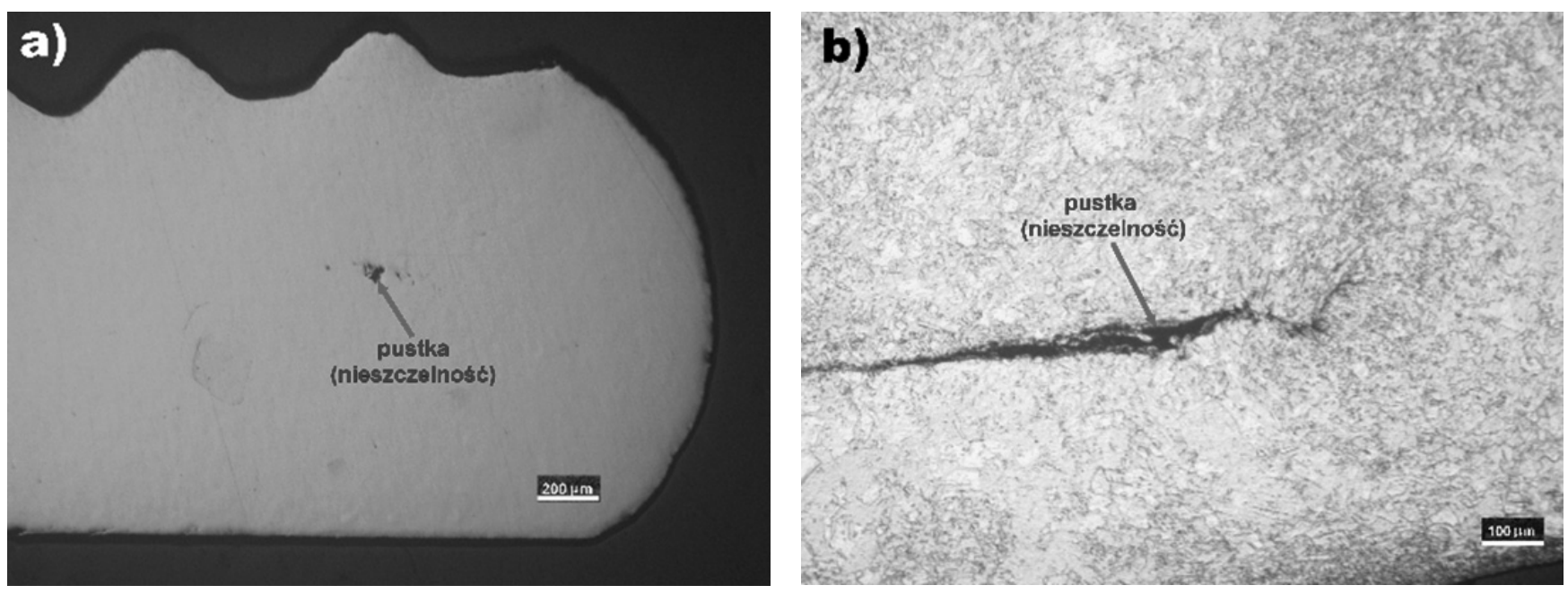

Rys. 9. Makrofotografie złącza zgrzewanego ultradźwiękowo: a) próbka nietrawiona, b) płaszczyzna zgładu wskazana na rysunku 5c Fig. 9. Macrophotographs of an ultrasonically welded joint: a) non etching sample, b) plane of cross section indicated in figure $5 \mathrm{c}$

widoczna jest pusta przestrzeń w której znajdują się drobiny miedzi oderwane od powierzchni wewnętrznej rurki oraz zanieczyszczenia. Na rysunku 8 przedstawiono przekrój złącza zgrzewanego, które było poddane dodatkowo badaniom na tomografie komputerowym. Na zgładzie nietrawionym widać wyraźnie pustkę leżącą w linii styku. Pustka na zgładzie trawionym wypełniona jest luźnymi cząstkami materiału oderwanymi od powierzchni wewnętrznej rurki.

Z przeprowadzonych badań metalograficznych wynika, że nieszczelności w złączach zgrzewanych ultradźwiękowo rurek pojawiają się tylko na brzegach połączenia, natomiast w środkowej części styku wykazują poprawną budowę złącza.

Mikrostrukturę poprawnie wykonanego złącza zgrzewanego ultradźwiękowo w części brzegowej przedstawiono na rysunku 10. Linia styku jest mocno rozgałęziona wskutek przestrzennej deformacji materiału rurki miedzianej, lecz nie występują w niej pustki skutkujące nieszczelnością złącza.

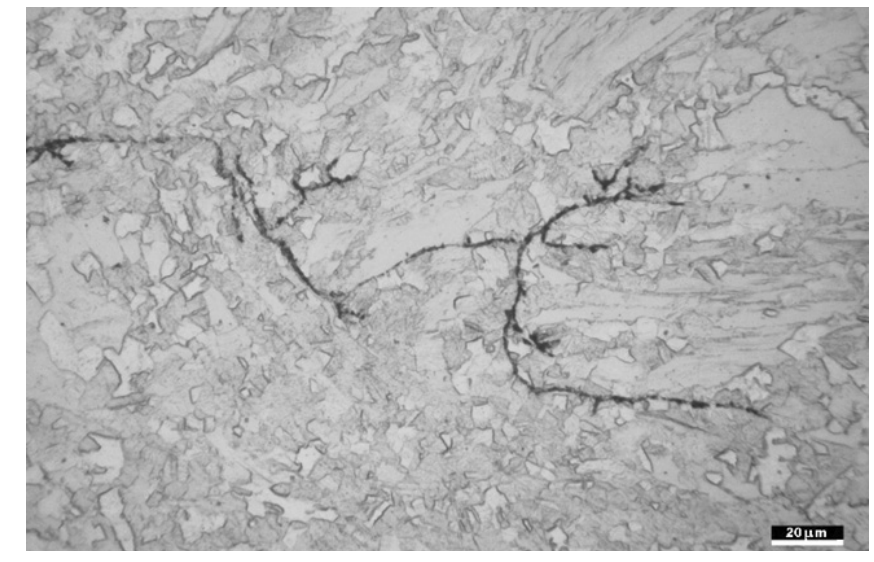

Rys. 10. Mikrofotografia poprawnie wykonanego złącza zgrzewanego ultradźwiękowo na jednym z końców złącza szczelnego

Fig. 10. A micrograph of a correctly made ultrasonic welded joint at one end of a sealed joint

\section{Podsumowanie}

Badanie z wykorzystaniem tomografii komputerowej umożliwiło zobrazowanie przestrzennej charakterystyki złączy zgrzewanych. Wykazało występowanie nieciągłości wewnątrz zgrzeiny, oraz okre-śliło ich pozycję i wymiary. Ilościowa ocena nieciągłości i nieniszczący charakter badań CT pozwala na znaczne rozszerzenie możliwości analizy złączy zgrzewanych i ocenę ich jakości, uzupełniając rezultaty uzyskane na podstawie badań metalograficznych.

Przeprowadzone badania metalograficzne wykazały, że nieszczelności w złączach zgrzewanych ultradźwiękowo rurek miedzianych pojawiają się tylko na brzegach połączenia, natomiast w środkowej części styku wykazują poprawną budowę zgrzeiny.

Z przeprowadzonych badań metalograficznych wynika również, że oprócz parametrów zgrzewania istotny wpływ na jakość złączy zgrzewanych ultradźwiękowo mają też warunki technologiczne procesu takie jak czystość powierzchni (warstwa tlenków i zanieczyszczeń na powierzchni), równomierność docisku powierzchni szczęk zgrzewarki powodujący różny stopień zgniotu na przekroju zgrzeiny.

\section{Literatura}

[1] Jasiulek P.: Łączenie tworzyw sztucznych metodami spawania, zgrzewania, klejenia i laminowania, Wyd. Kabe, 2014.

[2] Matsuoka S., Imai H.: Direct welding of different metals used ultrasonic vibration, Journal of Materials Processing Technology. Vol 209, № 2, 2009.

[3] Daxin R., Kunmin Z., Min P., Ying Ch., Song G., Dewang Z.: Ultrasonic spot welding of magnesium alloy to titanium alloy, Scripta Materialia, 126, 2017.

[4] Fujii H.T., Goto Y., Sato Y.S., Kokawa H.: Microstructure and lap shear strength of the weld interface in ultrasonic welding of Al alloy to stainless steel, Scripta Materialia, Vol. 116, 15 April 2016.
[5] Al-Sarraf Z., Lucas M.: A study of weld quality in ultrasonic spot welding of similar and dissimilar metals. Journal of Physics: Conference Series 382, 2012, 012013

[6] Ambroziak A.: Zgrzewanie tarciowe materiałów o różnych właściwościach, Oficyna Wydawnicza Politechniki Wrocławskiej, 2011.

[7] Matheny M.P., Graff K.F.: Ultrasonic welding of metals. EWI, Columbus, $\mathrm{OH}, \mathrm{USA}$. 